\title{
SDGs: Bridging of Science and Innovations with Local Conditions
}

Salme Timmusk*

Uppsala BioCenter, SLU, Dept. of Forest Mycology and Plant Pathology, P.O Box 7026, SE-75007 Uppsala, Sweden

*Corresponding author: Salme Timmusk, Uppsala BioCenter, SLU, Dept. of Forest Mycology and Plant Pathology, P.O Box 7026, SE-75007 Uppsala, Sweden, Tel No: 018-672727; E-mail: salme.timmusk@slu.se

Received date: November 15, 2016; Accepted date: November 25, 2016; Published date: December 02,2016

Copyright: (c) 2016 Timmusk S. This is an open-access article distributed under the terms of the Creative Commons Attribution License, which permits unrestricted use, distribution, and reproduction in any medium, provided the original author and source are credited.

\section{Editorial}

Agriculture faces several unexpected challenges at global level but in low income countries these challenges are particularly acute as the agriculture represents the dominant part of their economy. Food and water shortages can lead to further unrest and wars. There is significant international consensus around the set of normative goals (SDGs) for food and water security in the changing climate. Yet the visions materialization calls for bridging to local practices and conditions [1-3]. Development Research Conference 'Global Visions and Local Practices Development Research in a Post-2015 World was held in Stockholm, August 22-24, 2016 [4].

What is the best way to design helping programs? How should the academic institutions interact? What is the role of knowledge production in the new policy context? In order to reduce vulnerability of the countries to climate change agricultural technologies should be environmentally friendly (i), ensure high productivity (ii) and be suitable for small-holder farmers adaptation (iii). These goals can only be achieved via development of innovative interdisciplinary technologies.

Panel 'Food and Water Security via Viable Business Models' comprised of various presentations concerning innovations to be implemented in low income countries. Dr. Timmusk research group presented their results on application of native soil bacteria application for crop water productivity and soil structure improvement. Drought with low nutrient efficiency is a major agricultural problem in subSaharan Africa. The beneficial native soil bacteria which increase crop drought tolerance and nutrient use were isolated from harsh environments in Israel and Arizona, USA, and developed for field application in Ethiopia. The studies reveal five times greater survival and $78 \%$ higher biomass in inoculated plants under severe drought stress. The rhizobacteria were formulated using crystalline $\mathrm{TiO} 2$ nanoparticles for encapsulation. Coalescence of nanoparticles selfassembling on the surface of cell membranes leads to formation of dense and stable shells able to improve survival and function of rhizobacteria. The research project is part of the larger framing project for food and water security and deals with the major cereals in East and Central Africa (ECA). The developed products and precision management strategies will be appropriate tools for irrigation engineering improving agricultural water productivity in ECA. Based on the triangular model of the proposed networking, the research innovations are implemented in training centres called Farmers Filed Schools (FFS) which are connected to the outreach centres in the ECA countries (Figures 1a-1c).

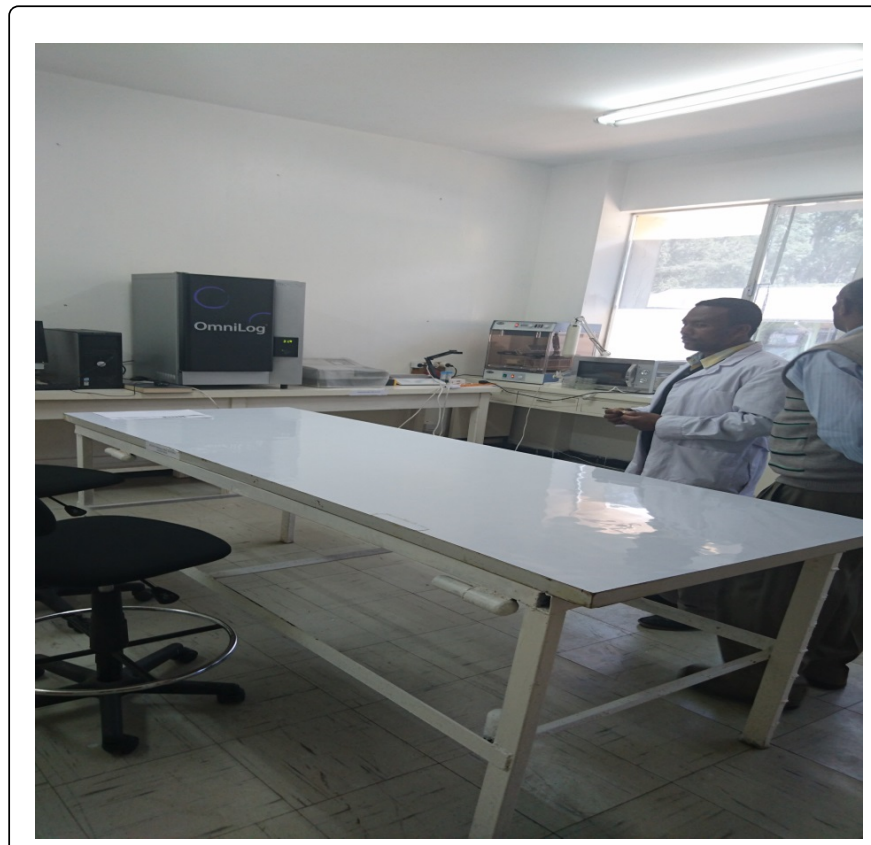

Figure 1a: Capacity building collaborations at the Institute of Biotechnology, Addis Ababa University.

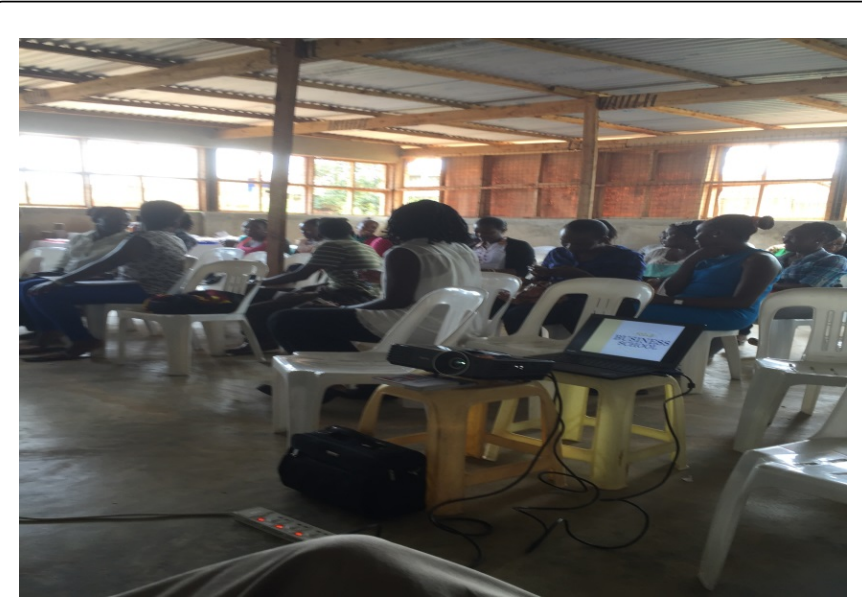

Figure 1b: Centre of Development\& Outreach (SOHA), Kampala Ultuna. 


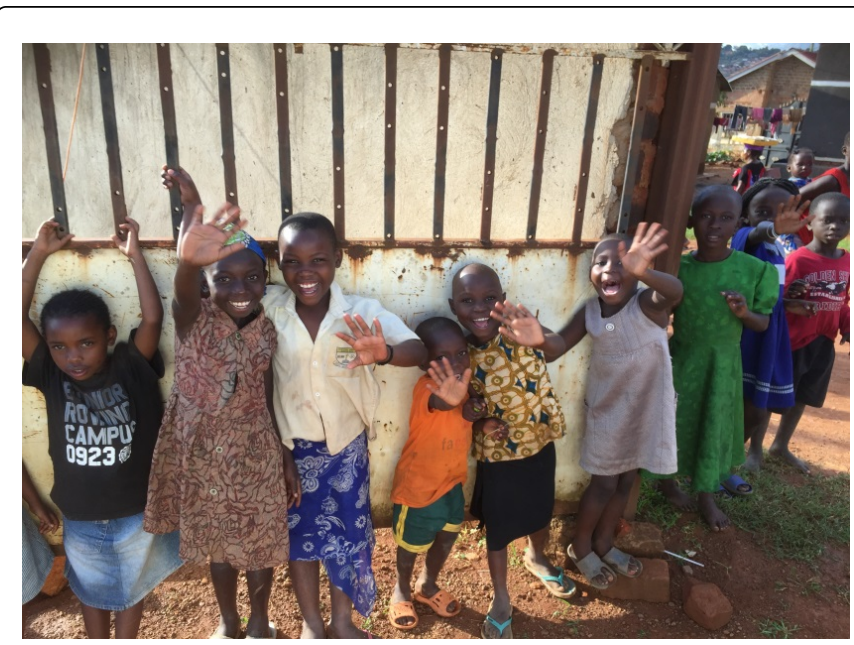

Figure 1c: Centre of Development\& Outreach (SOHA), Kampala Ultuna.

Agriculture is imbedded in a political and socio-economic environment and any innovative technology has to be scaled for local environment. Favourable policy environment should be established (iiii) to bring in the wide scale change to the food and water security situation in the targeted countries. The innovative programs should engage in a sustainable way, which means increase of yield in the context of scarcity of natural resources and threats against fragile livelihoods, and at the same time, facing constraints linked to climate change, competing energy chain values and dwindling natural resources. The innovations should be linked to capacity building, in terms of human, institutional competence development and infrastructure establishment [5].

The official representative form His Royal Highness of the Kingdom of Kooki, Uganda participated in the event. The King in Uganda wants to facilitate innovations for villages. The representative presented the letter from the King. The Kingdom of Kooki offers 30 acres of land to facilitate implementation of the innovations in the model village and businesses created on the land. Vivid discussion took place following His speech. How does His Royal Highness see the implementation of 17 SDGs, research, innovations, patenting policy and local businesses in His country? The Kooki Kingdom representative stated an interest in speeding up the climate change adaptation processes in Uganda, and that the kingdom is not just waiting for the help from outside but is interested in active contribution. Being well aware of the global and local challenges, the kingdom sees part of the solution to the challenges by welcoming research innovations on Farmers Field School (FFS) based business models on the land offered. FFS are tightly connected to educational outreach centres taking care of marginal vulnerable groups. He would see Swedish and international help in research and innovation based business development as a seed investment until it is self-sustaining [6]. The policy will reduce the number of economic refugees and the businesses built on the land would also provide opportunities for the low income country students to return and apply the knowledge acquired in Sweden and in other helping countries. Quite often students cannot return due to low income and no conditions to apply their knowledge in their home country. It is more popular to find possibilities to stay elsewhere abroad. This however, while helping few individuals would nullify policy to help the low income country. Instead it would rob off the talented people from the country, the representative of His Royal Highness stated.

It is clear that expected lasting impact of the international activities in low income countries calls for fundamental rethinking about how to design the helping programs. The purpose of the network was to propose a model where the capacity building collaborations link academic institutions and outreach projects. This demands understanding of local enabling environments, taking advantage of local knowledge and competences. Any action taken in the targeted countries in order to adapt to the climate change should be seen as socio-political processes where decisions are embedded in the arrangements of the local authority.

\section{References}

1. Nilsson M, Griggs D, Visbeck M (2016) Policy: Map the interactions between Sustainable Development Goals. Nature. 534: 320.

2. Fluckiger Y, Seth N (2016) Sustainable Development Goals: SDG indicators need crowdsourcing. Nature. 531: 448.

3. Haas PM (2016) Sustainable Development Goals: create a coordinating body. Nature. 535: 493 .

4. http://www.humangeo.su.se/english/development-researchconference-2016.

5. http://www.humangeo.su.se/english/development-researchconference-2016/programme/panels/panel-36-1.270623.

6. Timmusk S, Copolovici L, Tanilas T, Kannaste A, Behers L etal., (2014) Drought-tolerance of wheat improved by rhizosphere bacteria from harsh environments: enhanced biomass production and reduced emissions of stress volatiles. PloS ONE. 9: e96086. 